\title{
NOTES ON SOME GENERA OF BLATTIDÆ.
}

\author{
By A. N. Caudell.
}

U. S. National Museum, Washington, D. C.

The genus Steleopyga was established by Fischer von Waldheim in $1833^{1}$ with three included species, orientalis, americana and trichoprocta, the last a new species and the first two, while not so listed, are known to be the Blatta orientalis of Linnæus and the Blatta americana of the same author. Now the type of Steleopyga must be one of the three above mentioned originally included species. The first of the originally included species, orientalis, is not eligible as it was designated as the type of Blatta by Latreille in $1810 .^{2}$ To date, so far as I know, orientalis is the only one of the originally included species that has been designated as type of Steleopyga. ${ }^{3}$ The type is therefore as yet undesignated. The second originally included species, americana, has long been the designated type of Periplaneta, thus eliminating it from consideration as the type of Steleopyga. The third and last of the originally included species, trichoprocta, becomes therefore the type of Steleopyga.

Blatta aegyptica Linnaeus, the type species of the genus Polyphaga of Brullé, has as a synonym the Steleopyga trichoprocta of Fischer, shown above to be the type of Steleopyga. Thus Polyphaga Brullé and Steleopyga Fischer, having synonymous species as types, are themselves synonymous. Polyphaga therefore falls as a synonym of Steleopyga, being the more recent by two years. 2 Blatt., p. 30 (1907), designates Blatta rhombifolia Stoll as type of Stylopyga but it is not an originally included species of that genus.

In $1846^{4}$ Fischer introduced a different spelling of his genus Steleopyga, spelling it Stylopyga, crediting it to himself, quoting the reference to its original proposal in 1833 and including but a single species, Blatta orientalis Linnæus, which is figured. This is obviously but a different spelling, or an emendation, of Steleopyga but it has recently been used as a distinct genus by Mr. Shelford, ${ }^{5}$

1 Bull. Soc. Imp. Nat. Moscou, vol. vi, p. 356, 366 (1\$33).

3 Consid. Crust., Arach. \& Ins., p. 246.

shelford, Sjöstedt's Expedit. Kilim. Meru \&c., 17, Orth.

- Orth. Russie, p. 65.

6 Genera Insectorum, Fasc. 109, p. 14 (1910). 
who quotes the original Steleopyga in the synonymy under Blatta. The only species, orientalis, included under this emended form by Fischer is not ineluded by Shelford, who uses the name for a group of species typlified by the Blatta rhombifolia of Stoll. This group of speeies which Mr. Shelford lists under Stylopyga is separable from the species of the genus Blatta only by the length and development of wings in the male and can thus all be logically referred to that genus. Therefore the twenty-five species listed by Shelford in the above paper are transferred to the genus Blatta.

The genus Dorylixa of Stal is very closely allied to Blatta and will eventually very likely prove a synonym of that genus.

\title{
LUCILIA SERICATA AS A HOUSEHOLD PEST.
}

\author{
Br A. P. Monse, \\ Wellesley College, Mass.
}

In October, 1910, a lady asked me, "Why do worms prefer oriental rugs to Wilton carpets?" Inquiry revealed the fact that one of her friends was finding large numbers of white "worms" under her oriental rugs.

Naturally my first thought was of fleas and Dermestid larræ, but the description was at variance with either, neither dogs or cats were about, the rugs had been recently cleaned, and the house was immaculately kept,- -so I requested samples. In a few days a vial containing several Museid maggots and a puparium was received. Careful questioning in regard to food material for such ereatures finally secured the information that a squirrel family had been evieted recently from one of the chimneys and that one of the young squirrels, it was believed, liad died in the flue. This clue accounted satisfactorily for the presence of the troublesome maggots and the sequel. With this introduction, the following extracts from letters coneerning the outbreak will be self explanatory, due allowance being made, if thought necessary, for a possible, but under the cireumstances, very pardonable, exaggeration in regard to the numbers of the pest.

[Nov. 23] "Mrs. - writes me that you would like to hear about our 'squirrels.' On Sept. 17 squirrel No. 1 eame down the chimney and took possession of the lower part of the house, 

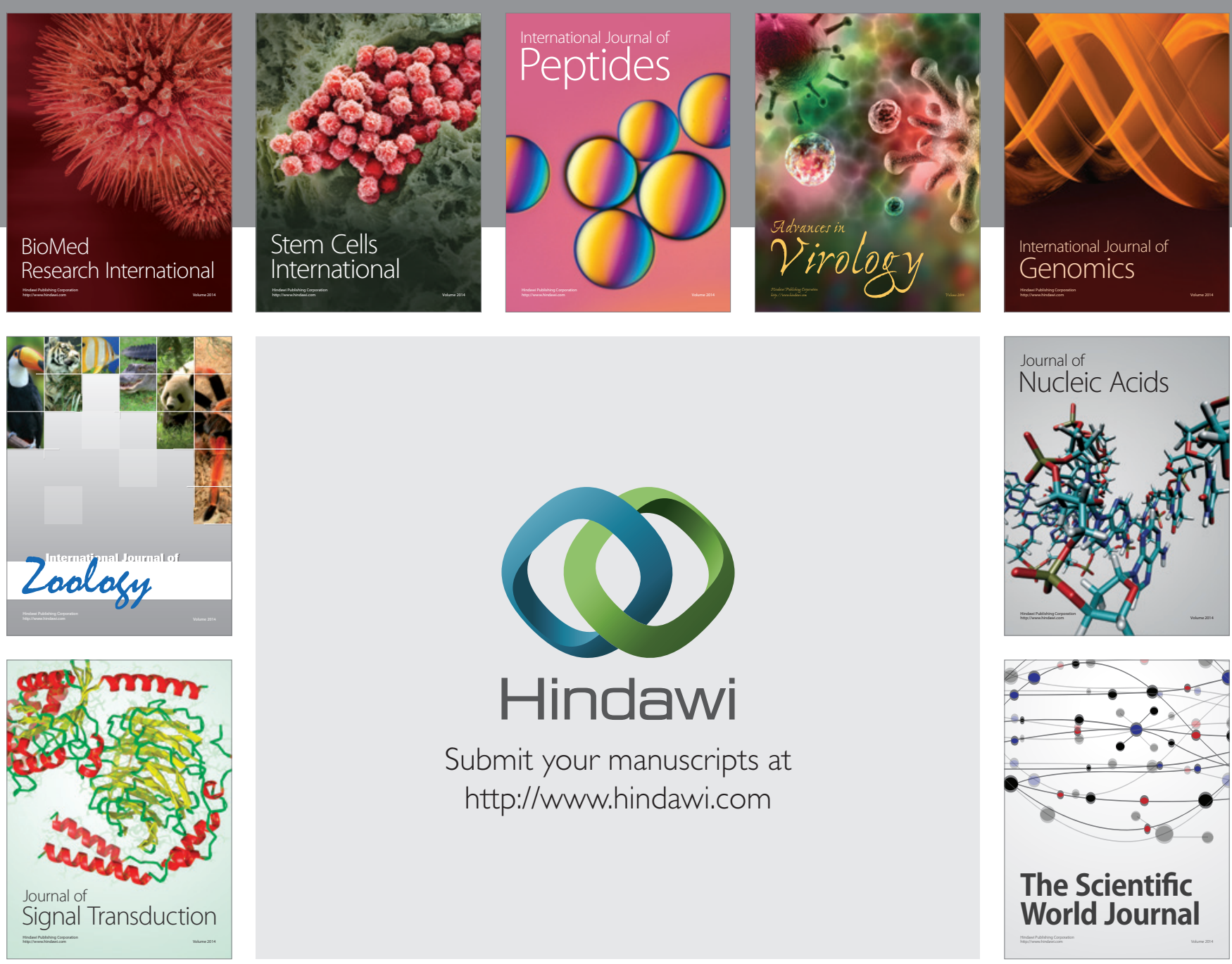

Submit your manuscripts at

http://www.hindawi.com
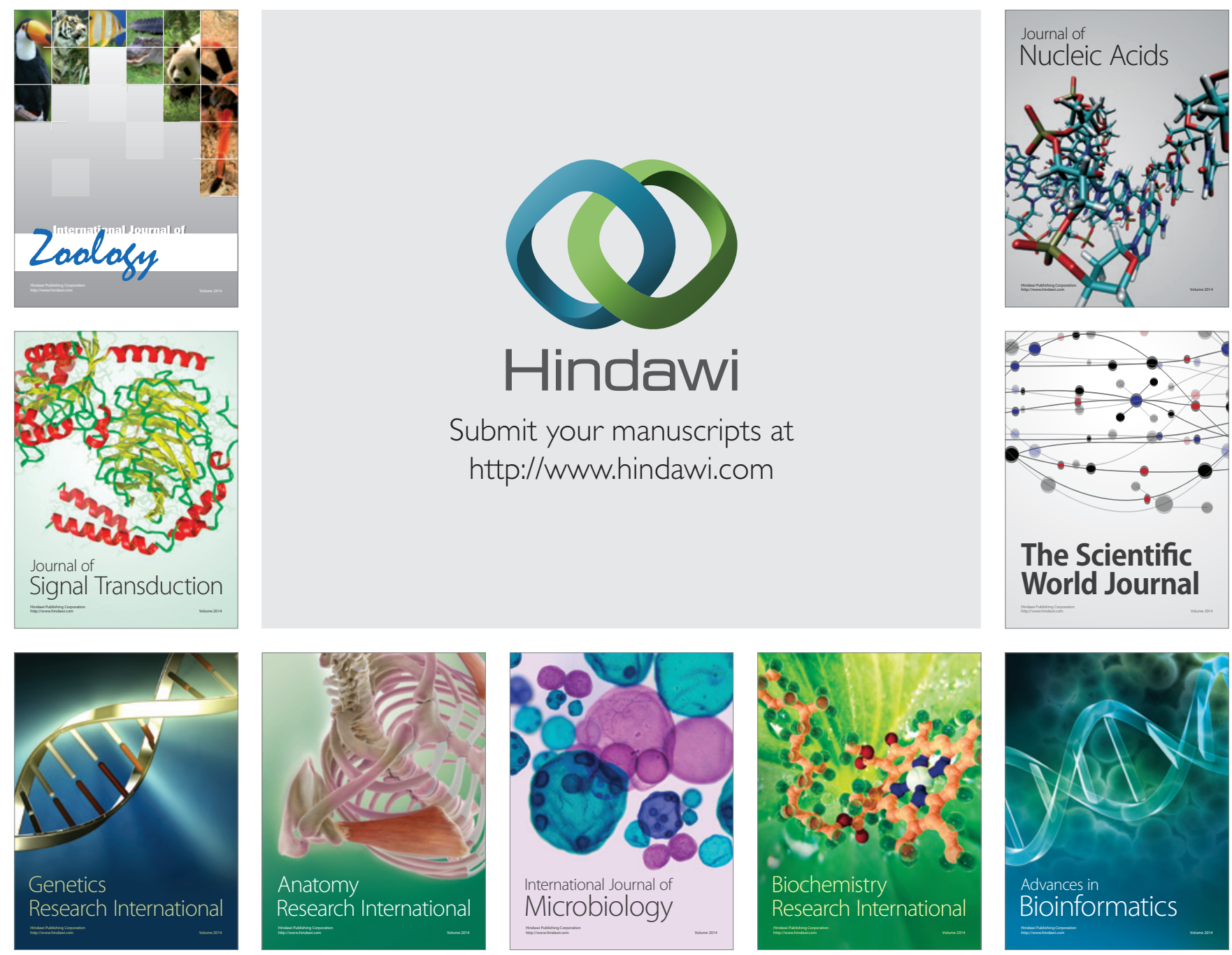

The Scientific World Journal
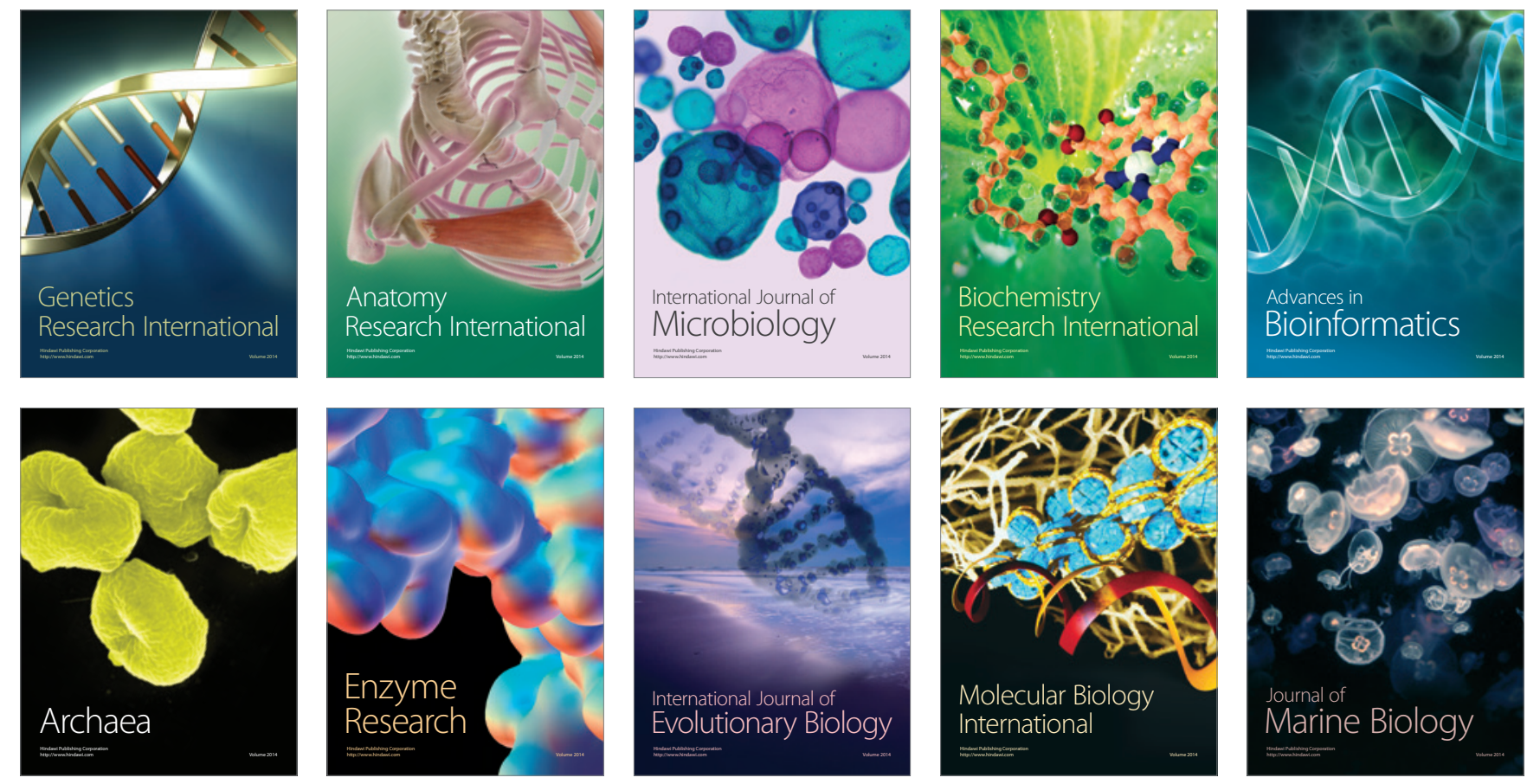